\title{
Application of Operational Risk Assessment in Inventory Management and Reputational Risk of Chip-Based Electronic Money: KLM Bank Case Study
}

\author{
Kadek Dwi Juliana Lestari, Lufti Julian*
}

Faculty of Economics and Business, Universitas Indonesia, Jakarta, Indonesia

${ }^{*}$ Corresponding author. Email: lufti.joelian@gmail.com

\begin{abstract}
This study discusses the application of operational risk assessments, inventory management, and reputational risk of chip-based electronic money at KLM Bank. Chip-based electronic money is issued by KLM Bank to answer the challenges of disruptions. The purpose of this study is to understand the product's operational and reputational risk, so that it can provide the mitigations needed to contribute positively to bank-wide performance. This study uses a qualitative case-study methodology. Data was collected from interviews and documentation. The operational risk of chip- based electronic-money inventory management is caused by a mismatch of needs at the branch, as a sales unit, whereas the reputational risk may arise from failure to top up or of shopping transactions or by the risk of nonfulfillment of customer requests and balance updates. The results of the study suggest applying inventory restrictions at the branch level to mitigate operational risk, and routine socialization of the managers that initially handle complaints to mitigate reputational risk.
\end{abstract}

Keywords: Disruptions, Operational Risk, Reputational Risk, Chip-Based Electronic Money

\section{INTRODUCTION}

The rapid development of technology has encouraged every industry to become more creative and innovative, including the banking industry. One of the challenges in the banking industry is the financialtechnology industry's participation, which disrupts the world banking industry, forcing it to evaluate and invest in digital innovations, such as electronic money. Based on data from Bank Indonesia (2018), the amount of electronic money issued in Indonesia has experienced average compound growth (CAGR) of $36 \%$ in six years.

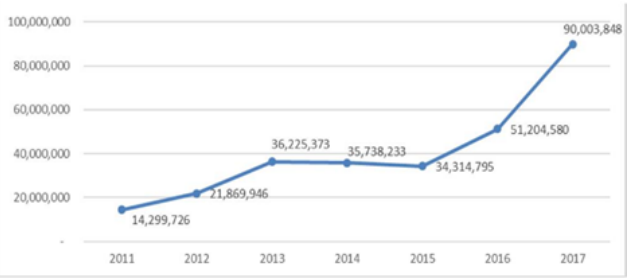

Figure 1. Amount of Electronic Money Circulating in Indonesia
Technology use in banking (digital banking) requires high reliability over service availability and, simultaneously, increases security threats. The implementation of digital banking provides three benefits for banks-namely, the deployment of cheap funds, efficiency rather than having to invest in branch offices, and receiving fee-based income from customer transactions. Jasmine (2018), as quoted by Galvan (Kontan 2018), said that PT Bank Mandiri Tbk noted that as many as 95 percent of banking transactions were carried out in the digital-banking channel in 2017, whereas only 5 percent of transactions were carried out at branch offices. Digital banking in this context also includes electronic money products, especially chipbased electronic money.

The growth trend in the amounts and number of electronic money transactions certainly increases operational and reputational risk in its management for the issuer of electronic money. KLM Bank, as one of the issuers of chip-based electronic money since 2009, is certainly exposed to operational and reputational risk 
in the provision of services. The main objective of KLM Bank in developing chip-based electronic money is to support the National Non-Cash Movement (GNNT) and support the growth of the cashless society, which was launched in 2006. In addition, development is also carried out to address the disruption challenges shown by the emergence of new competition in the financial industry. KLM Bank, which is currently a major player in the electronic-money business, has generated more than $\$ 15$ million by recording the frequency of e-money transactions, which reached 880 million transactions with a total value of IDR 10 trillion by the end of Q3 2018. KLM Bank's fee-based income from issuing electronic money has increased concurrent with the increase of cards sold. These products can support KLM Bank's strategic initiatives, but good internal management controls are needed, so that it is effective, efficient, has economic value, and can mitigate any possible operational, reputational, strategic, legal, and compliance risks.

The difference between this research and previous research related to banking and bank risk is that the discussion will focus on the operational and reputational risk of chip-based-electronic-money management, a KLM Bank service, whereas most of the existing research focuses more on the operational risk of lending.

The contribution of this study is operational and reputational risk-mitigation recommendations for chipbased-electronic-money management processes, based on case-study methods tested at a bank in Indonesia, which can be implemented to support product sustainability and help bank-wide performance.

This research uses case-study analysis and field studies with data-collection techniques suitable for research, including documentation, interviews, and observation. This study consists of an introduction, literature review, methodology, analysis and discussion, and conclusions and suggestions. The introduction discusses the research background, problem formulation, questions to be answered in this study, and the research purpose, benefits, and scope. The literature review discusses studies about the three lines of defense, disruptions, the main risks in banking, the Committee of Sponsoring Organizations Enterprise Risk Management (COSO ERM) framework, and electronic money. The methodology section discusses the research methods and approaches used, including the authors' reasoning behind choosing the methods, as well as data-collection and data-analysis techniques. The results-and-discussion section presents the research findings on operational and reputational risk assessment in managing chip-based electronic money at KLM Bank and provides recommendations that companies can implement. This is followed by a section with conclusions about the discussed results.

\section{LITERATURE REVIEW AND HYPOTHESIS DEVELOPMENT}

\subsection{Three Lines of Defense}

The application of the Three Lines of Defense (3LD) strategy is based on the amount and complexity of risk a company faces, which requires layered management. Toburen and Potter (2016) explain that the application of 3LD carried out on existing risk-related business functions to determine a company's risks. Toburen and Potter (2016) also explain that this model works well to eliminate the inefficiency, distance, and overlapping functions that often occur in risk management and related functions. The 3LD framework can be seen in figure two.

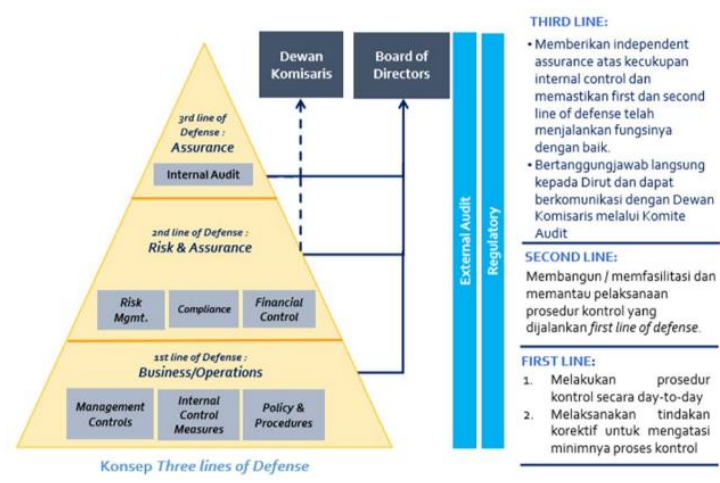

Figure 2. Three Lines of Defense (3LD) Concept in Bank Mandiri [15]

A company's application of 3LD can help it do a better job of cooperating to manage risk by creating more strategic relationships between the three lines of defense, thereby encouraging managers to take risks and auditors to focus on governance structures and strategic values. Managers are then assessed for responsibility in overall risk performance, not only by the number of findings that appear in the audit report.

\subsection{Disruptions}

Disruptions can be interpreted as changes that alter existing conditions, activities, and/or processes. Kasali (2017) explains that disruptions are triggered by two things-rapid technological development and the millennial generation or Gen $\mathrm{Y}$, the latter being a generation that has been immersed in technology since birth. PricewaterhouseCooper (2017) defines disruptions as significant, fast, and potentially unplanned or unexpected events that create potential risks and opportunities, which demand attention and resources from a business. Kasali (2018a) explains that disruptions are innovations that create new markets, economic volatility, regulatory changes, or even catastrophic events. The rapidly changing and unpredictable market requires that businesses anticipate and react to all types 
of changes to survive and develop. Technological advances can cause disruptions in all industries, including financial services.

Kasali (2017) said that an important part of disruptions theory is business processes. This should be of particular concern to incumbent companies currently in business. Technology reduces $1 \mathrm{ong}$ processes. To shorten distance and time in the digital ecosystem, fundamental changes in three areas are required: resource allocation, business process, and values. According to Kasali (2017), these three areas affect response speed, the ability to read new signals, and a cheaper cost structure. Digital ecosystems form connections, thus making everything interconnected and easily building socioeconomic activities. The more fertile the ecosystem, the greater the network that forms because of greater sharing benefits for each party. To illustrate, 2014-2017 disruptions in China created a cashless society with penetration of up to 90 percent. Almost all payments are now made using a $\mathrm{QR}$ code in the WeChat/Alipay application.

\subsection{Main Risks in the Banking Business}

BSMR (2018) identifies eight types of risks that those in the banking business are exposed to:

- Credit risk-risk that a debtor (borrower) will not pay the agreed-upon principal and interest in a timely manner, otherwise known as defaulting (default)

- Market risk-risk arising from the movement of market variables, interest rates, and exchange rates, which affect a bank's portfolio and can adversely affect its income

- Operational risk-risk arising from the inadequacy and/or nonfunctioning of internal bank processes due to human error, system failure, or external problems that affect a bank's operations

- Liquidity risk-risk partly due to a bank's inability to fulfill maturing obligations

- Strategic risk-risk caused by improper decisionmaking or lack of bank responsiveness to external changes

- Reputational risk-risk included in the operational- risk category, which arises from, among other things, negative publications relating to banking activities or negative general perceptions

- Legal risk-risk that arises because of bank management's inability to manage emerging legal problems that could cause losses or bankruptcy for the company; legal risks can come from operations, third-party agreements, legal uncertainty, negligence in applying the law, obstacles in the process of settling litigation claims, and jurisdiction issues between countries

- Compliance risk-risk caused by a bank's noncompliance in implementing legislation or other applicable provisions

\subsection{COSO ERM Framework}

COSO ERM is a risk-management framework published by the Committee of Sponsoring Organizations of the United States Treadway Commission in 2004. COSO ERM has eight components that are interrelated, visualized as a cube, which can be implemented effectively to achieve corporate goals and objectives in four categories. The eight components are internal environment, objective setting, event identification, risk assessment, risk response, control activities, information and communication, and monitoring.

\subsection{Electronic Money}

Based on Bank Indonesia Regulation (PBI) 11/12 / PBI / 2009, electronic money is a payment instrument with the following characteristics [4]:

- Based on the amount of money paid to the issuer in advance

- Stored electronically with a medium such as a server or chip

- Not a deposit, as per banking law

Bank Indonesia (2009) distinguishes two types of electronic money, based on the balance-value storage:

- Chip—stored on a chip embedded into a card

- Server-stored on a server connected to the internet; payment or funds transfer is done real time on the internet

\section{RESEARCH METHOD}

The method used in this reseach was a descriptive case study that aimed to examine risk assessment for chip-based-electronic-money management, then provide recommendations on how to optimize inventory management and minimize complaints related to electronic-money services. 


\subsection{Data-Collection Technique}

In this study, interviews were conducted with respondents at KLM Bank to find out the company's situation and its method of chip-based-electronicmoney management. The data used in this study are primary data obtained from respondents who are risk owners or business units and from an internal audit of KLM Bank. The researchers chose the internal auditor because the person has in-depth access to and understanding of the product-management process and ofinternal and external product regulations. The risk manager was chosen to determine the unit's role in researching the risk of chip-based electronic money. Researchers chose business managers based on the branches that make direct sales to merchants and consumers and which are risk owners. Researchers also conducted interviews with the head- office management, which is responsible for monitoring, productmanagement documentation, and compiling productperformance reports and which is a risk owner. The aim was to obtain comprehensive information and advice that can be applied at KLM Bank. The secondary-data sources used in this study were the company's annual audit plan and its chip-based-electronic-money inventory-management report, which were used to a limited degree.

\subsection{Data-Analysis Technique}

After the data were collected, an operational-risk assessment for inventory management and a reputational-risk assessment related to complaints regarding product service were conducted. The aim was to determine the frequency and impact of these risks on the company's operations. The results of the risk assessment will be used as input to develop an audit program related to chip-based-electronic-money management. Once recommendations have been made, researchers will communicate the study results to the department head for use as a reference to optimize chipbased-electronic-money management and minimize the number of complaints related to chip-based-electronicmoney services.

\section{RESULTS AND DISCUSSION}

\subsection{Application of 3LD to Chip-Based Electronic Money}

The implementation of 3LD for chip-basedelectronic-money management involves several functions. The first line at KLM is the Electronic Channel Operations (ECO) group, whose main functions are performing day-to-day control procedures and carrying out corrective actions to overcome any lack of control processes. The second line is the risk manager, who facilitates and monitors the implementation of control procedures carried out by the first line of defense. The Senior Operational Risk-TI and Operation (SOR-TIO) is an operational-risk-management department that, together with the risk-management department, maps key processes and risk events, prepares control testing scripts for each business process, and carries out inherent assessments. The risk owner's department also periodically conducts operational-riskmanagement control testing on the risk-management department, in accordance with the specified period, and evaluates residual risk. The compliance department is tasked with ensuring that the risk of compliance with external chip-based-electronic-money regulations is appropriate and that there are no violations. The third line is carried out through internal audit, which provides assurance and consulting services related to operational risk and chip-based-electronic-money management.

\subsection{Disruptions and the Business of Chip- Based Electronic Money at KLM Bank}

KLM Bank sees Bank Indonesia's electronic-money policies as an opportunity that not only supports BI policies but also creates new value for KLM Bank. The feature of chip-based electronic money that KLM Bank highlights on its website is Radio Frequency Identification (RFID) technology, which allows cardholders to make a transaction by just tapping their card to a reader. To see how disruptions can occur in the payment system for multifunctional payment cards that provide convenience and change business processes, there is the example of implementing noncash toll payments on October 31, 2017. When Bank Indonesia and toll-road operators required noncash payments on toll roads, it was a huge, innovative change that made past practices seem outdated. The value proposition or the value of benefits offered by chip-based electronic money to each related party can be classified as follows:

a. Card owners: no need to bother carrying cash to make purchases; the charged amount will be right, so no congestion at the toll from waiting for change

b. Government and Bank Indonesia: helps monitor and control the money supply in the community; BI does not need to provide large amounts of small denominations for toll operators

c. Toll ope rat ors: spee ds up ser vice, re duces the cost of transporting physical money, facilitates reconciliation because the reader records numbers, fewer operators needed due to cost efficiency, improves security at toll gates

d. Publishers of electronic money: improved services, branding, increased low-cost funds, increased feebased income from card sales, and partnerships with merchant businesses. 


\subsection{COSO ERM at KLM Bank and Identification of Electronic-Money Risks}

Based on KLM Bank's Internal Control Policy, in 2017, the internal control system consisted of eight mutually related components that are effectively implemented by bank employees to achieve bank objectives. KLM Bank uses the COSO cube model in the implementation of an internal control system wherein periodic and continuous effectiveness evaluations are carried out. The risk-identification and risk-assessment processes at KLM Bank are conducted using an impact-like hood matrix. This research focuses on the assessment of operational and reputational risk arising from operational risk, so that the impact factors that are suitable for use are financial, reputational, and customer service.

The risk assessment inherent in chip-basedelectronic-money operations is carried out by the SOR-TIO (risk manager) and business units, as outlined in the 2016 electronic-money management (Standard Operating Procedures). The chip-basedelectronic-money business continues to grow alongside customers' needs for chip-based electronic money. It is necessary to assess new operational risks that arise along with business growth. This study aims to assess operational and reputational risk by using internal audit data, which acts as a third line of defense, such that the assessed risk will be an additional operational and reputational risk for electronic-money management SPO. This study's limitation is that it cannot display all the results of the SOR-TIO's (risk manager's) assessment, so the assessment data will be carried out by the researcher based on the results of interviews with KLM Internal Audit Bank where internal audit data is the result of chip-basedelectronic-money inspection that has been communicated first with the SOR-TIO (risk manager).

\subsection{Findings Related to Chip-Based- Electronic-Money Management}

Based on the risk assessment and interviews with Head of internal audits (2018) that conduct site visits and checks of branches and ECOs, there are some risks that need to be mitigated by classification.

The results of interviews with the internal-audit team explain several findings related to operational-risk number one, whereas operational-risks numbers three and four have been properly mitigated operationally with the automatic-reversal system in the card owner's account, but sometimes there have been complaints related to these risks, such that they can affect reputational risk.

Findings related to inventory management (operational-risk one) were obtained after inspecting several branch especially branches that had the most inventory, and having discussions with marketing personnel and parties that receive multiple orders from branches to be forwarded to ECO for printing. The internal-audit team also conducts discussions about and checks on the documentation carried out by the ECO team and the results of the MPS system pulls. Several significant findings are as follows:

- Based on the data query for chip-based-electronicmoney card inventory in the positioning system in August 2018, there are 136,808 cards still listed as part of branch inventory, with the longest input year being 2009 .

- There are 6,419 "X card" type prepaid cards still recorded in systems spread across branches. The $\mathrm{X}$ card cannot be sold because it uses old chips, and now the $\mathrm{X}$ card is no longer manufactured.

As a result of this stock buildup and the card status not being updated in the system, the branch's card stock becomes idle because the $\mathrm{X}$ card cannot be sold by the branch because the system error during the card-sale because it was not allocated a budget for the previous card request. The proposed recommendation is coordination between ECO and the informationtechnology (IT) department to verify whether or not card stock that is still recorded as inventory in the system has been sold. If there are prepaid cards that have been sold but are still listed as inventory in the system, a patching process should be carried out, so that the status of the cards becomes "issued" ("I"). Monthly regional reconciliation to monitor branch card stock is necessary. It is further reommended that, if one card area exceeds 1,000 cards, the region be obliged to return old card stock, due to an updated reader system that can cause old cards to be unused and unable to be sold. If a card is returned, the card can be reset by the IT team, so that it can be read by a new reader. $\mathrm{X}$ cards that cannot be used should be returned to the vendor, so that they can be reprinted according to the current system. 
Table 1. Summary Risk Assessment

\begin{tabular}{|c|l|l|l|}
\hline No. & \multicolumn{1}{|c|}{ Category } & \multicolumn{1}{c|}{ Risk } & \multicolumn{1}{c|}{ Cause of Risk } \\
\hline 1 & High (16) & Operational & Lack of monitoring and administration of electronic-money \\
\hline 2 & High (15) & Reputational & Negative news in the mass media regarding electronic-money \\
\hline 3 & Medium to High (12) & Operational & System failed to complete the electronic-money top-up process \\
\hline 4 & Medium to High (9) & Operational & Transaction failure, but the electronic-money balance is reduced \\
\hline 5 & Medium (6) & Operational & Nonfulfillment of customer requests for electronic money \\
\hline
\end{tabular}

Table 2. Branch Inventory Check

\begin{tabular}{|l|c|c|}
\hline \multicolumn{1}{|c|}{ Region } & Inventory & X Cards \\
\hline Region I & 8,990 & 236 \\
\hline Region II & 4,095 & - \\
\hline Region III & 28,806 & 840 \\
\hline Region IV & 23,757 & 355 \\
\hline Region V & 17,816 & 341 \\
\hline Region VI & 10,895 & 11 \\
\hline Region VII & 10,877 & 3,207 \\
\hline Region VIII & 14,557 & 281 \\
\hline Region IX & 10,017 & 776 \\
\hline Region X & 1,530 & 72 \\
\hline Wilayah XI & 4,256 & - \\
\hline Wilayah XII & 147 & - \\
\hline $\begin{array}{l}\text { N/A (branch has } \\
\text { relocated) }\end{array}$ & 1,065 & 300 \\
\hline \multicolumn{1}{|c|}{ Total } & $\mathbf{1 3 6 , 8 0 8}$ & $\mathbf{6 , 4 1 9}$ \\
\hline
\end{tabular}

Reputational risk regarding electronic-money services is caused by all the above-mentioned operational risks and is categorized as high, so it needs to be mitigated. A reputational risk that cannot be properly mitigated will result in a decline in the company value in the eyes of the consumer. The expectations of chip-based-electronic-money users about product performance and how complaints are handled affects reputational risk. The results of interviews with one of the branch heads and the consumer-care team who were able to access the complaints-recording system at KLM Bank show that there are still frequent complaints from card users triggered by the process can result in the stock recorded in the system to not be in accordance with the physical card stock. This certainly results in less-than-optimal revenue from card sales. A well-managed stock could potentially increase revenue for KLM Bank and certainly improve services for customers who order chip-based electronic money, orders which cannot be accommodated at this time because card stock is spread out across branch areas and ECO cannot print cards again presence of operational risks, as indicated by the results of the risk assessment.

The results of interviews with internal-audit teams, branches, and customer-complaint-management team indicate that there are recurrent complaints related to chip-based electronic money, most of which are related to failures during the refill process, balance update, and transactions. The causes of customer complaints are: first, a broken chip that causes the transaction to be denied; second, the limited capacity of the KLM Bank server hampers top-ups and updating the balance on the card. Thirdly, customer's negligence in updating the balance through the process of tapping an ATM reader or NFC on a customer's mobile phone via the preinstalled KLM Bank application. This process is important to do so that the card balance can be updated according to the balance that has been topped up before. As a result of the failure that occurred earlier the customer was unable to make transactions using the card and caused customer dissatisfaction with KLM Bank services, this certainly affected the reputation of KLM Bank. Customer dissatisfaction can increase if the settlement process does not meet customer expectations or requires a long time. To mitigate this risk, branches or call centers that receive customer complaints must do documentation through the system, so KLM Bank can get data about the problems that often happen. Complaint data can be used for service improvement efforts. Improvement efforts that have been made starting on August 30, 2018, KLM Bank renewed the service level agreement (SLA) service for complaints related to electronic money, namely for complaints made up to at $15.00 \mathrm{WIB}$ will be processed by the SLA on the same day, while for complaints made after 15.00 WIB will be processed on the next working day, where the previous SLA is 7 Business Days. This SLA is required to be socialized to all units that handle customer complaints, so that customer satisfaction and KLM Bank's reputation can improve.

An operational risk that also affects reputational risk is the risk of nonfulfillment of requests from branches and sales which are requests from customers for cobranding chip-based electronic money. Chip-based branding electronic money is one of the strategies of KLM Bank to increase market share and value of products that are expected to contribute positively to the achievement of bank-wide. The cause of this risk is that the ECO unit does not budget for ordering new blank cards to be printed at the customer's request and also due to the less optimal management of card inventory which causes a buildup in branches that do not meet the needs of the branch. ECO cannot print all branch requests and marketing, because the budget must also 
be planned and utilized according to the target, so that branch orders and marketing will be delayed to the next year's budgeting period. Demand for branches and Marketing that cannot be met will result in customers looking for other chip-based electronic money publishers that have services such as KLM Bank and reducing the chances of increasing other incomes for KLM Bank.

\section{CONCLUSION AND IMPLICATION}

The assessment of operational and reputational risk in the management of chip-based electronic money at KLM Bank is done by using a matrix likelihood and impact which results in a score on each identifiable risk. The risk identified is the result of an examination carried out by the Internal Audit of KLM Bank as a third-line defense, which aims to provide assurance that internal control of chip-based-electronic-money operations is sufficient. Operational risks that have the highest scores include operational risk management, risk of nonfulfillment of customer requests, risk of a top-up process failure, balance updates, and failure to shop at merchants. These operational risks can cause reputational risk at KLM Bank, especially the risks directly related to the customer.

Suggestions that can be given to KLM Bank Internal is to improve coordination between the management, sales and IT groups in order to facilitate the card inventory verification process which is still recorded as inventory on the system and in the warehouse. In addition, more rigorous monitoring is needed regarding the ordering of new cards by paying attention to the availability of inventories in the branch, and monitoring idle card inventory in each branch area so that if a branch cannot sell all of its card inventory, the inventory can be allocated to meet customer demand at other branches and fee-based income will be more optimal. Chip-based-electronic-money cobranding strategy can be improved by paying attention to input from the business unit of the customer management so that it is expected to improve the service and reputation of KLM Bank. It is expected that with the synergy between Bank HIMBARA, one chip-based electronic money can be issued that has all the features of the Bank HIMBARA card, so customers do not have to bother carrying lots of cards.

\section{RESEARCH LIMITATIONS}

The limitations of this study are limited to the assessment of operational risk and the risk of reputation of chip-based electronic money issued by the bank, while the types of electronic money currently experiencing business growth are not only chip-based electronic money but also server-based electronic money in the form of applications on mobile phones and scan payment QR code both issued by banks and fin-tech players.

Suggestions for further research are research for server- based electronic money issued by banks or fintech. Future research is expected to enrich knowledge related to electronic money and the risks faced in managing and developing the product.

\section{ACKNOWLEDGMENTS}

This research was presented in The 4th Asia-Pacific Forum for Research in Social Sciences and Humanities 2019 hosted by the University of Indonesia. We appreciate valuable feedback and comments from the conference participants to improve our research paper.

In addition, we also thank Ibu Siti from KLM Bank who provided her insight and expertise in internal audit and banking industry.

\section{REFERENCES}

[1] Banirestu, H., dan Suryadi, D. (2017). Bank Mandiri Digital Banking: Salah Satu Pilar Retail Banking. SWA, 42-43.

[2] Bank Indonesia. (2006a, Mei). Mendorong Terbentuknya Less Cash Society. Siaran Pers Bank Indonesia database.

[3] Bank Indonesia. (2006b). Persepsi, Preferensi Dan Perilaku Masyarakat Dan Lembaga Penyedia Jasa Terhadap Sistem Pembayaran NonTunai.

[4] Bank Indonesia. (2009a). Peraturan Bank Indonesia nomor: 11/12/PBI/2009 Tentang Uang Elektronik (electronic money). Jakarta: Bank Indonesia.

[5] Bank Indonesia. (2009b). Peraturan Bank Indonesia nomor: 11/25/PBI/2009 Tentang Perubahan atas PBI No.5/8/PBI/2003 tentang Penerapan Manajemen Risiko bagi Bank Umum. Jakarta: Bank Indonesia.

[6] Bank Indonesia. (2014, Agustus). Bank Indonesia Mencanangkan Gerakan Nasional Non Tunai. Siaran Pers Bank Indonesia database.

[7] Bank Indonesia. (2018a). Informasi Perizinan Penyelenggara dan Pendukung Jasa Sistem Pembayaran. Jakarta: Bank Indonesia.

[8] Bank Indonesia. (2018b). Instrumen Pembayaran Nontunai. Jakarta: Bank Indonesia.

[9] Bank Indonesia. (2018c). Statistik Sistem Pembayaran. Jakarta: Bank Indonesia.

[10] Committee of Sponsoring Organizations of the Treadway Commission. (2013). Internal ControlIntegrated Frame work. 
[11] Kasali, Rhenald. (2017). Tommorrow is Today. Inilah InovasiDisruptif Perusahaan Indonesia dalam Menhadapi Lawan-Lawan Tak Kelihatan. Series on DISRUPTION. Jakarta. Mizan.

[11] Kasali, Rhenald. (2018a). Self DisruptionBagaimana Perusahaan Keluar dari Perangkat Masa Lalu dan Mendisrupsi Dirinya Menjadi Perusahaan yang Sehat. Series on DISRUPTION. Jakarta. Mizan.

[12] Kasali, Rhenald. (2018b). The Great ShiftingLebih Baik Pegang Kendali Daripada Dikuasai. Series on DISRUPTION. Jakarta. Mizan.

[13] Mulyaningrum, Martha D., Topowijono, dan Zahroh ZA (2016). Analisis Manajemen Risiko Perbankan Dalam Meminimalisir Kredit Bermasalah Di Bidang Kredit Modal Kerja (Studi Pada Pt Bank Rakyat Indonesia (Persero) Tbk. Cabang Jombang). Jurnal Admi nistrasi Bisnis (JAB)|Vol. 32 No. 1 Maret 2016. 121-127.

[14] Mustaslimah (2018). Innovation Audit: How it can Impact the Organization. Paparan pada Kuliah Umum Internal Audit 2 tanggal 30 April 2018.

[15] Nikabadi, Mohsen Shafiei \& Seyed Mahmoud Mousavi. (2016). The Effect of E-Money on the NonFinancial Performance of Banks (Case Study: Bank Mellat of Iran). International Journal of Innovation in the Digital Economy. Volume 7 • Issue 1
[16] Nketsiah, Thomas Addae. (2013). Combating Money Laundering and Financing of Terrorism: The Role of Banks in Ghana. The University of Ghana.

[17] Pickett, K.H. Spencer. (2005). Auditing the Risk Management Process. New Jersey; John Wiley \& Sons, Inc.

[18] Potter, Patrick dan Marshall Toburen. (2016). The 3 Lines of Defense for Good Risk Management.

[19] Suzianti, Amalia., Rachma Hidayati, dan Erlinda Muslim. (2015). Perancangan Roadmap Produk dan Teknologi pada Uang Elektronik Chip-Based di Indonesia. Program Studi Teknik Industri, Fakultas Teknik, Universitas Indonesia.

[20] The Institute of Internal Auditors. (2004). Applying COSO's Enterprise Risk Management Integrated Framework.

[21] The Institute of Internal Auditors. (2013). IIA Position Paper: The Three Lines of Defense in Effective Risk Management and Control.

[22] Untoro, Priyo R. Widodo, Wahyu Yuwana, Komala Dewi, Retni Cristina S. (2014, Desember). Layanan Keuangan Digital: Hambatan Dan FaktorFaktor Penentu Keberhasilan. Bank Indonesia.

[23] Yin, Robert K. (2008). Studi Kasus Desain dan Metode. Jakarta: Raja Grafindo Persada. 